Pomáhajúce profesie, roč. 4, č. 2, 2021, 40-47

\title{
KVALITA ŽIVOTA U ZÁVISLÝCH OD PSYCHOAKTÍVNYCH LÁTOK V ÚSTAVNEJ LIEČBE ZÁVISLOSTÍ
}

\author{
Richard Wolt1ㄹ,2, Ema Micháleková1, Jana Uhláriková1 \\ ${ }^{1}$ Katedra psychologických vied FSVaZ UKF Nitra \\ ${ }^{2}$ Centrum pre liečbu drogových závislostí Banská Bystrica \\ rwolt@ukf.sk
}

\begin{abstract}
Abstrakt: Ciel'om bolo analyzovat' rozdiel v prežívaní kvality života u závislých od psychoaktívnych látok na konci ústavnej liečby v porovnaní s jej začiatkom. Výskumný súbor tvorilo 80 respondentov, z toho 57 mužov a 23 žien, ktorí sa liečili v Centre pre liečbu drogových závislostí Banská Bystrica $(\mathrm{M}=41,86 ; \mathrm{SD}=11,58)$. Na zistenie kvality života bol použitý dotazník WHOQOL - BREF (Dragomirecká a kol., 2006). Zistili sme významný rozdiel vo všetkých dimenziách kvality života a tiež aj v prežívaní celkovej kvality života a zdravotného stavu u závislých od psychoaktívnych látok na konci ústavnej liečby v porovnaní s jej začiatkom. Uvedené zistenia vo výskume diskutujeme.
\end{abstract}

Kl'účové slová: kvalita života, závislost', liečba závislostí

\section{1 ÚVOD}

Problematika závislosti od psychoaktívnych látok je jedným z najzávažnejších problémov súčasnej spoločnosti. Podl'a Hellera (1996) spôsobuje telesné i duševné zmeny, ako aj zmeny v správaní i v emóciách Pre jednotlivcov závislých od drog je prežívanie kvality života a interpersonálnych vzt'ahov pomerne nízke. Užívanie návykových látok má negatívne účinky na jednotlivca z hl'adiska jeho zdravotného i psychického zdravia, sociálnych vzt’ahov, subjektívneho prežívania a prostredia (Dzúrová, 2000). Negatívne účinky na všetky oblasti kvality života vyplvajú zo skutočnosti, že u závislých droga zastupuje v ich rebríčku hodnôt prvé miesto. Tým strácajú záujem, zanedbávajú sociálne, rekreačné, pracovné aktivity a potešenie nachádza len v užívaní drogy (Nešpor, 2003). Pri znižovaní škôd spôsobenými psychoaktívnymi látkami je dôležitý liečebný proces smerovaný $\mathrm{k}$ abstinencii a zmene životného štýlu.

\subsection{Kvalita života}

O kvalite života môžeme uvažovat' ako o multidimenzionálnom koncepte, ktorý je dynamický, kultúrne podmienený a zahŕňa biologické, psychologické, ekonomické, estetické, sociálne, etické i filozofické faktory (Vad'urová, Mühlpachr, 2005). Strieženec (1999, s. 20) definuje kvalitu života ako „...súhrn objektívne i subjektívne posúditel’ných stránok činností a vnemov človeka v jeho každodennom živote, $\mathrm{v}$ reálnom sociálnom priestore $\mathrm{s}$ konkrétnymi pravidlami vzájomného spolužitia s reálnymi otázkami ciel'a, zmyslu a údelu pozemského života...". Pojem kvality života sa spája s rozmanitými oblast'ami života a môžeme sa na ňu pozerat' z rôznych uhlov pohl'adu, čo potvrdzuje aj Mühlpachr (2002) tým, že kvalitu života chápe ako subjektívny a individuálny aspekt l'udského bytia, ktorý sa uplatňuje pre rôznych l'udí v rôznom čase. Do konceptu kvality života rovnako zahŕňa vek, zdravie, telesnú a psychickú výkonnost', pohlavie, rodinnú situáciu, životnú úroveň, úroveň vzdelania ako aj profesijný status. Podl'a Svetovej zdravotníckej organizácie je kvalita života komplexné meranie fyzickej, psychickej a sociálnej pohody, št'astia, spokojnosti a naplnenia tak, ako ju vníma jednotlivec alebo skupina. Do konceptu kvality života môžeme tiež 
zaradit' aj spokojnost' a nespokojnost' s okolím, samostatnost' v sebaobsluhe, pohyblivost', subjektívne hodnotenie svojej vlastnej životnej situácie. Kvalita života je výsledkom osobných hodnôt a životného štýlu, pričom samotné prežívanie života pokryje individuálne, psychologické i fyzické priania a potreby. Rovnako zaznamenáva rozdiel medzi prianím a očakávaním jednotlivca a jeho skúseností (Dragomirecká, Škoda, 1997).

Kvalita života a jej ponímanie v medicíne sa často odráža od subjektívnej pocitu životnej pohody, ktorý sa asociuje s ochorením, úrazom, liečením a vedl'ajšími účinkami. Medicínsky prístup sa zameriava aj na pozitívne stránky zdravotného stavu jednotlivca a posudzuje jeho zdravotno duševný stav za účasti psychopatológie či výkonu pracovných a sociálnych funkcií. Tento prístup zahŕňa celkový záujem jednotlivca ako pacienta o svoj zdravotný stav (Dragomirecká a kol., 2006). Psychologický prístup sa orientuje na snahu popísat’ subjektívny stav prežívania životnej pohody a celkovú spokojnost' s vlastným životom (Hnilicová, Bencko, 2005).

Svetová zdravotnícka organizácia nachádza východisko v rámci ukazovatel'ov kvality života v definovaní štyroch základných oblastí, ktoré sa vnútorne delia na d'alšie indikátory. Medzi tieto základné štyri domény radí:

- Telesné zdravie a úroveň nezávislosti, medzi ktoré zarad'uje indikátory ako energia a únava, bolest' a nepohoda, spánok a odpočinok, mobilita, aktivita v každodennom živote, závislost' od liekov a pracovná kapacita.

- Psychické funkcie zahŕňajú indikátory ako imidž vlastného tela a zjavu, negatívne a pozitívne emócie, sebahodnotenie, myslenie, učenie, pamät', pozornost', spiritualita a osobné presvedčenie.

- $\quad$ Sociálne vzt'ahy, ktoré zahŕňajú osobné vzt’ahy, sociálnu podporu a sexuálne aktivity.

- Prostredie, ktoré zahŕňa indikátory ako: finančné zdroje, sloboda, fyzická bezpečnost', zdravotná a sociálna starostlivost', prostredie domova, príležitost' získat' informácie a kompetencie, vol’nočasové a rekreačné aktivity, fyzikálne prostredie ako sú emisie, doprava a klíma (Hrozenská, 2011).

\subsection{Závislost'}

Za závislost' môžeme označit' návykové užívanie psychoaktívnej látky aj napriek tomu, že po ňom nasledujú negatívne dôsledky. Jedinca premáha túžba drogu užívat' niekedy častejšie inokedy menej. Aby sme mohli závislost' potvrdit', musia sa prejavit' aspoň tri symptómy počas jedného roku (Nešpor, 2003). Medzi tieto symptómy patrí túžba po droge, ktorá býva neprekonatel'ná. Najsilnejšia je na začiatku abstinencie, postupne intenzita túžby klesá, ale môže sa opätovne objavit' aj po dlhotrvajúcej abstinencii (Kolibáš, Novotný, 2007). Ďalším symptómom je neschopnost' ovládat' svoje správanie, pretože túžba zhoršuje sebaovládanie. Telesný odvykací stav je d’alším symptómom, s ktorým závislost' rastie. Prejavuje sa celkovým nekl'udom organizmu, potením, triaškou, zrýchleným tepom, nespavost'ou, nechut'ou do jedla, či bolest'ami hlavy. Pre každý druh drogy sa prejavuje iný príznak odvykacieho syndrómu. (Nešpor, 2003). Droga sa pre závislého stáva cennejšia ako čokol'vek iné, rastie necitlivost' voči látke, stráca sa kontrola nad sebou samým a látka sa stáva hodnotou nad všetkým čo bolo pre jedinca doteraz dôležitým. Podl’a Medzinárodnej klasifikácie chorôb (MKCH - 10) môžeme závislost' charakterizovat' ako:

- Skupinu fyziologických, behaviorálnych a kognitívnych fenoménov, v ktorých užívanie nejakej látky má u daného jednotlivca ovel'a väčšiu prednost' ako iné jednanie, ktoré si predtým cenil viac.

- Silnú túžbu alebo silný pocit nutkania brat' psychoaktívne látky alebo opätovne pocit’ovat' účinky psychoaktívnej látky, s ktorou mal už jednotlivec skúsenost'.

- Problémy v sebaovládaní, kedy jednotlivec nevie mat’ pod kontrolou svoje správanie a emócie.

- Problémy v kontrole užívania látky. 


\section{Pomáhajúce profesie, roč. 4, č. 2, 2021, 40-47}

- Zvyšujúca sa tolerancia (potreba väčších dávok drogy, aby sa dosiahol požadovaný účinok).

- Zanedbávanie záujmov a nachádzanie potešenia len v užívaní drogy (stereotypné správanie).

- Pokračovanie v užívaní aj napriek škodlivým následkom (sociálne, psychologické alebo telesné problémy).

- Užívanie látky k odstráneniu somatických telesných znakov (Nešpor, 2003).

Obraz o kvalite života u závislých od psychoaktívnych látok prináša výskum Dzúrovej (2000). Jedinci so závislost’ou od psychoaktívnych látok majú významne vyššiu nespokojnost' v oblastiach psychickej pohody, prostredia, domova a spánku, rodiny, interpersonálnych vzt'ahov, lásky, zál'ub, bezpečia a slobody. Dlhodobé užívanie drogy má vel'mi nepriaznivý účinok na zdravotný stav. Závislí často nepracujú a strácajú záujem o vzdelanie, pretože im neustále zháňanie drogy zaberá všetok čas. Vzdelanie považuje Možný (2002) za nevyhnutnú súčast' kvality života u každého jednotlivca. Podl'a výsledkov výskumu Doležalovej (2006) klienti terapeutických komunít určených pre dlhodobú liečbu závislých uvádzali nižšiu spokojnost’ v oblasti financií, lásky, sexu, politiky, práce, zál'ub a interpersonálnych vzt’ahov v porovnaní s kontrolnou skupinou. Hudáková s Magurovou (2011) zistili, že 30\% z celkového počtu liečiacich sa závislých žien vykazovalo celkové zhoršenie kvality života, pričom až $70 \%$ z nich uvádzalo dlhodobé pretrvávanie negatívnych pocitov.

K zmierneniu negatívnych dopadov závislosti môže významne prispiet' liečba. Tá môže prebiehat' vo forme ambulantnej a ústavnej. Väčšina závislých je na začiatku liečby k jej absolvovaniu motivovaná vonkajšími faktormi, ktorými sú rodina, práca či zdravie. Počas liečby je dôležité zvnútornit' motiváciu, aby závislý chcel abstinovat' najmä kvôli sebe, nie kvôli druhým. Tento posun je možný uskutočnit' len v prípade, že jednotlivec porozumie svojej chorobe, bude schopný sebareflexie a zbaví sa racionalizácií, ktorými ospravedlňoval svoje správanie (Profous, 2011). Liečba závislosti je rozdelená na etapy. Prvou etapou je detoxikácia, kedy sa znižujú najmä zdravotné komplikácie. Využíva sa tu najmä farmakologická liečba, ale podporená je tiež psychoterapiou, v ktorej sa pacientovi snaží terapeut vysvetlit' jeho problém a motivovat' ho $\mathrm{k}$ liečeniu závislosti. Druhou etapou je dlhodobá liečba, ktorá sa realizuje v špecializovaných zariadeniach. Takáto liečba sa odporúča u tých pacientov, u ktorých hrozí vysoké riziko relapsu. $\mathrm{V}$ tejto fáze liečby je dôležité narušit' pacientove obranné mechanizmy, akými sú napríklad bagatelizácia a racionalizácia. Táto fáza zahŕňa aj pokračovanie v skupinovej a individuálnej psychoterapii. Ciel'om psychoterapie by malo byt' nielen dosiahnutie abstinencie, ale najmä jej udržanie. Aby pacient dokázal abstinovat' dlhodobo, vel'ký dôraz sa kladie aj na celkovú osobnostnú zmenu a zmenu v sebahodnotení. Súčast’ou liečby je tiež rehabilitácia telesná, sociálna a psychologická, v ktorej sa pacient učí reagovat' na rôzne situácie bez užitia návykovej látky. Tret'ou fázou je fáza doliečovania. $V$ tejto fáze sa pacientovi neodporúča len navštevovanie psychiatrickej ambulancie, ale tiež podporných skupín, ako sú skupiny anonymných alkoholikov, socioterapeutické kluby, terapeutické komunity a iné. Poslednou fázou je obdobie zamerané na prevenciu relapsu. Je to práca na identifikácii a zmene problematického správania sa a učení vhodných reakcií, kde vždy na prvom mieste musí byt’ abstinencia pacienta. Pacient si vytvára vlastné individuálne stratégie, ktoré mu majú pomôct' vyhnút' sa v krízových situáciách recidíve (Kolibáš, Novotný, 2007).

Na základe teórie a výsledkov štúdií možno predpokladat', že hodnoty dimenzií kvality života u závislých od psychoaktívnych látok v liečbe sa budú výrazne líšit' ku konci liečby v porovnaní s jej začiatkom. Formulovali sme nasledovné hypotézy: 
H1: Predpokladáme, že závislí od psychoaktívnych látok budú dosahovat’ na konci ústavnej liečby štatisticky významne vyššie hodnoty v dimenzii kvality života - Fyzické zdravie v porovnaní so začiatkom ústavnej liečby.

H2: Predpokladáme, že závislí od psychoaktívnych látok budú dosahovat' na konci ústavnej liečby štatisticky významne vyššie hodnoty vdimenzii kvality života - Prežívanie v porovnaní so začiatkom ústavnej liečby.

H3: Predpokladáme, že závislí od psychoaktívnych látok budú dosahovat’ na konci ústavnej liečby štatisticky významne vyššie hodnoty v dimenzii kvality života - Sociálne vzt'ahy v porovnaní so začiatkom ústavnej liečby.

H4: Predpokladáme, že závislí od psychoaktívnych látok budú dosahovat’ na konci ústavnej liečby štatisticky významne vyššie hodnoty v dimenzii kvality života - Prostredie v porovnaní so začiatkom ústavnej liečby.

H5: Predpokladáme, že závislí od psychoaktívnych látok budú dosahovat' na konci ústavnej liečby štatisticky významne vyššie hodnoty v dimenzii kvality života - Celková kvalita života v porovnaní so začiatkom ústavnej liečby.

H6: Predpokladáme, že závislí od psychoaktívnych látok budú dosahovat' na konci ústavnej liečby štatisticky významne vyššie hodnoty v dimenzii kvality života - Zdravotný stav v porovnaní so začiatkom ústavnej liečby.

\section{METÓDY}

\subsection{Výskumný súbor}

Výskumný súbor tvorilo 80 respondentov, ktorí boli hospitalizovaní v liečebnom zariadení v ústavnej liečbe závislostí. Výskumný súbor pozostával z 57 mužov a 23 žien vo vekovom rozsahu 19 - 63 rokov $(M=41,86 ; S D=11,58)$. Metódu výberu výskumného súboru sme realizovali príležitostným, zámerným výberom.

\subsection{Použité metódy}

Respondentom bol administrovaný dotazník merajúci kvalitu života WHOQOL-Bref (World Health Organization Quality of Life Assessment, Dragomirecká a kol., 2006). Dotazník pozostáva z 24 položiek, ktoré sú rozdelené do štyroch domén - Fyzické zdravie, Prežívanie, Sociálne vzt'ahy a Prostredie. Okrem toho obsahuje aj dve samostatné položky týkajúce sa Celkovej kvality života a Spokojnost' so zdravím (celkový zdravotný stav). Respondenti hodnotia jednotlivé položky na pät'bodovej škále. Reliabilita dotazníka preukazuje dobrú vnútornú konzistenciu všetkých domén (Džuka, 2014). Dotazník respondenti vypíňali dvakrát - na začiatku a na konci ústavnej liečby závislostí. Jeho vyplnením vyjadrili informovaný súhlas so spracovaním poskytnutých údajov.

\section{3 Štatistická analýza dát}

Dáta sme spracovali v štatistickom programe IBM SPSS Statistics 20. Na základe testov rozloženia dát sme pre overovanie hypotéz volili parametrické aj neparametrické testy.

\section{VÝSLEDKY}

Výsledky komparačnej analýzy uvádzame v tabul'ke č.1 a 2. V doméne Prostredie sme vzhl’adom k nerovnomernej distribúcii dát použili neparametrický Wilcoxonov test, u ostatných Studentov $\mathrm{t}$ test. 
Tabul'ka č.1 Komparačná analýza kvality života -parametrické testovanie

\begin{tabular}{lllllllll}
\hline \multicolumn{1}{c}{$\mathrm{d}$} & & $\mathrm{M}_{1}$ & $\mathrm{SD}_{1}$ & $\mathrm{M}_{2}$ & $\mathrm{SD}_{2}$ & $\mathrm{t}$ & $\mathrm{df}$ & $\mathrm{p}$ \\
\hline Fyzické zdravie & 22,26 & 3,81 & 23,57 & 3,13 & $-2,31$ & 79 & 0,02 & 0,36 \\
Prežívanie & & 19,13 & 3,19 & 20,91 & 3,27 & $-3,37$ & 79 & 0,00 \\
$\quad 0,53$ & & & & & & & & \\
$\quad$ Sociálne vzt'ahy & 9,20 & 2,48 & 10,42 & 2,68 & $-2,77$ & 79 & 0,00 & 0,43 \\
Celková kvalita života & 2,93 & 1,05 & 3,63 & 0,97 & $-5,43$ & 79 & 0,00 & 0,85 \\
Zdravotný stav & 3,02 & 1,05 & 3,63 & 0,98 & $-4,99$ & 79 & 0,00 & 0,66 \\
\hline
\end{tabular}

Legenda: $M$ - priemerná hodnota; SD - štandardná odchýlka; $t$ - výsledok Studentovho T-testu; df stupne vol'nosti; $p$ - hladina významnosti ( $p<.05) ; d$ - vecná významnost'

Tabul'ka č.2 Komparačná analýza kvality života - neparametrické testovanie

\begin{tabular}{llllll}
\hline & $\operatorname{Mdn}_{1}$ & $\operatorname{Mdn}_{2}$ & $\mathrm{z}$ & $\mathrm{p}$ & $\mathrm{r}_{\mathrm{m}}$ \\
\hline Prostredie & 27,00 & 29,00 & $-2,59$ & 0,01 & 0,07 \\
\hline
\end{tabular}

Legenda: Mdn - medián; Z - výsledok Wilcoxonovho neparametrického testu; $p$ - hladina významnosti ( $p<.05) ; \mathrm{rm}$ - vecná významnost'

Komparačná analýza preukázala existenciu štatisticky signifikantných rozdielov v hodnotení jednotlivých dimenzií kvality života ako aj jej celkovom hodnotení na konci ústavnej liečby v porovnaní s hodnotením ukazovatel'ov na jej začiatku. Stanovené hypotézy sme tak prijali. Z výsledkov, ktoré sú uvedené v tabul'kách č.1 a 2 tak vyplýva, že na konci ústavnej liečby dosahovali respondenti vyššie skóre v dimenzii Fyzické zdravie, Prežívanie, Sociálne vzt'ahy, Prostredie, Celková kvalita života a Zdravotný stav. Z hl'adiska vecnej významnosti sa vel'ký efekt rozdielu preukázal v dimenzii Celková kvalita života a Zdravotný stav. Stredný efekt rozdielu sa prejavil v dimenzii Fyzické zdravie, Prežívanie, Sociálne vzt’ahy. Malý efekt rozdielu sa preukázal v dimenzii Prežívanie.

\section{DISKUSIA}

Ciel'om výskumu bolo overit' existenciu signifikantných rozdielov v hodnotách dimenzií kvality života u závislých od psychoaktívnych látok na začiatku a na konci ústavnej liečby. Výsledky poukazujú na významne vyššie hodnoty dimenzie Fyzické zdravie na konci liečby v porovnaní s jej začiatkom. Podl'a Zábranského (2003) priame pôsobenie drogy spôsobuje vážne ochorenia fyzického i psychického charakteru, avšak jednotlivec s drogovo závislost'ou môže predíst' fatálnym následkom na organizmus pôsobením liečby, a tým si zvýšit’ ponímanie kvality života z pohl'adu fyzického zdravia. Benkovič a Garaj (2009) vo svojom výskume zistili štatisticky významnú zmenu vo vnímaní kvality života po absolvovaní liečby. Nadmerné a dlhodobé užívanie alkoholu a drog vedie ku oslabeniu organizmu, čo súvisí s náchylnost'ou na rôzne ochorenia. Počas liečby sa pacienti dostávali do procesu, kedy si boli schopní uvedomit’ aj ohrozenie svojho zdravia a tiež riziko nezvratných zdravotných problémov súvisiacich s užívaním psychoaktívnych látok. Prerušenie užívania psychoaktívnych látok sa ku koncu liečby prejavilo v zlepšení zdravotného stavu, telesnej výkonnosti a zdatnosti. Štatisticky významne vyššie hodnoty na konci liečby získali respondenti tiež v dimenzii Prežívanie. Závislý človek má významne nižšiu kvalitu života v oblasti psychickej pohody a psychického prežívania (Dzúrová, 2000). Klúčovou zložkou liečby a základným článkom systému starostlivosti o jednotlivcov závislých od psychoaktívnych látok je psychoterapia. Psychoterapia podnecuje a podporuje činností, ktoré napomáhajú priebežnému poznávaniu samého seba a osobnostnému rastu. Na základe sebareflexie nastáva lepšie 
uvedomovanie si problémov, ktoré užívanie psychoaktívnych látok spôsobuje. Čumittová a Pavelová (2006) vo svojom výskume potvrdzujú, že odliečení pacienti vykazujú v otázke telesného a duševného zdravia vyššie hodnoty indexu spokojnosti v porovnaní so štandardizovanou výskumnou vzorkou. Pacienti sú na konci liečby schopní adekvátnejšie vnímat' svoje prežívanie a s tým súvisiace emócie, zvládat’ ich konštruktívnym spôsobom. Signifikantný rozdiel sa potvrdil aj v dimenzii Sociálne vzt'ahy, v ktorej na konci liečby respondenti dosahovali vyššie skóre. Jedným z motívov, na základe ktorých sa závislý od psychoaktívnych látok rozhodne pre liečbu, sú aj narušené interpersonálne vzt’ahy. Liečba závislostí je zameraná nielen na zlepšenie fyzického a psychického stavu, ale má za ciel' aj nápravu narušených vzt'ahov. Podl'a Kalinu a kolektívu (2003) sa pacienti počas liečby učia pozitívnym sociálnym hodnotám, čo výrazne prispieva k zlepšeniu interpersonálnych vzt’ahov. Výsledky komparačnej analýzy preukazujú významne vyššie hodnoty v dimenzii Prostredie na konci liečby. Táto dimenzia zahŕňa aspekty ako finančné zdroje, sloboda, fyzická bezpečnost', zdravotná a sociálna starostlivost', prostredie domova, príležitost' získat' informácie a kompetencie, vol’nočasové a rekreačné aktivity a pod. V období užívania psychoaktívnych látok závislý stráca záujem o svoje prostredie, v ktorom sa nachádza (Zábranský, 2003) a vykazuje významne nižšiu kvalitu života v oblasti prostredia, domova a bezpečia (Dzúrová, 2000). Abstinencia prináša pozitívne zmeny v prežívaní a postojoch k prostrediu, v ktorom daný človek funguje. Dokáže mat' viac pod kontrolou svoje financie, je schopnejší a aktívnejší v riešení životných situácií a proaktívnom využívaní vol'ného času. Získané hodnoty preukazujú významne väčšiu spokojnost' s celkovou kvalitou života a zdravotným stavom na konci ústavnej liečby. Jedným z hlavných ciel'ov ústavnej liečby je znižovanie škôd vzniknutých ako následok dlhodobého užívania psychoaktívnych látok. Podl’a Orosovej (2003) liečba ovplyvňuje správanie $\mathrm{v}$ zmysle podpory zdravia. Liečebný proces je smerovaný $\mathrm{k}$ abstinencii klienta, na ktorý neskôr nadväzuje následná starostlivost' a doliečovanie, ktoré podporujú a udržiavajú zmeny a efekt liečby (Kalina a kol., 2003).

\section{LIMITY A ZÁVER}

Napriek výsledkom našej analýzy, ktorá naznačuje zaujímavé zistenia si uvedomujeme, že práca má viaceré limity a tak sme vel'mi opatrní pri zovšeobecňovaní interpretácií. Výskumný súbor nebol homogénny z hl'adiska veku, pohlavia a diagnózy. Stanovený ciel' výskumu sa nám podarilo naplnit'. Zistenia poukazujú na významný rozdiel v hodnotách dimenzií kvality života ako aj v celkovom prežívaní kvality života u závislých od psychoaktívnych látok na konci ústavnej liečby s porovnaním so začiatkom liečby. Ústavná liečba má podporujúci charakter, ktorý napomáha zvýšit' vnímanie subjektívnej kvality života. Uvedené zistenia sú kvantitatívneho charakteru, v d’alšom skúmaní kvality života v súvislosti so závislost’ou od psychoaktívnych látok by bolo podnetné skúmat' problematiku z hl'adiska kvalitatívneho prístupu.

\section{LITERATÚRA}

Benkovič, A., Garaj, V. (2009) Kvalita života l'udí závislých od alkoholu a jej zmena v priebehu liečby. Alkoholizmus a drogové závislosti, 44 (3), 129-152.

Čumittová, Z., Pavelová, L. (2006) Kvalita života odliečených závislých od alkoholu. Čistý deň, 4, 2627.

Doležalová, P. (2006) Kvalita života u drogově závislých v terapeutických komunitách. Adiktologie, 6 (1), 14-22. 
Dragomirecká, E. a kol. (2006) WHOQOL - BREF, WHOQOL - 100. Příručka pro uživatele české verze dotazníku kvality života Světové zdravotnické organizace. Praha : Psychiatrické centrum. 92 S.

Dragomirecká, E., Škoda, C. (1997) Kvalita života. Vymezení, definice a historický vývoj pojmu v sociální psychiatrii. Československá psychiatrie, 93 (2), 102-108.

Dzúrová, D. (2000) Příručka pro uživatele české verze dotazníku subjektivní kvality života SQUALA. Praha: Psychiatrické centrum. 68 s.

Džuka, J. (2014) Subjektívne hodnotená kvalita života - validita a reliabilita merania. Prešov: FF Prešovská univerzita. $103 \mathrm{~s}$.

Heller, J. a kol. (1996) Závislost známa neznámá. Praha: Grada Publishing, Avicenum, 162 s.

Hnilicová, H., Bencko, V. (2005) Kvalita života - vymezení pojmu a jeho význam pro medicínu a zdravotnictví. Praktický lekář, 85(11), 656-660.

Hrozenská, M. (2011) Kvalita života starších l'udí v priestore spoločenských vied. Nitra: Effeta. 155 s.

Hudáková, A., Magurová, D. (2011) Chronický alkoholizmus žien versus kvalita ich života. Adiktologie, 11 (3), 148-154.

Hyman, S.E. (2007) The neurobiology of addiction: implications for voluntary control of behavior. American Journal of Bioethics, 7 (1), 8-11.

Kalina, K. a kol. (2003) Drogy a drogové závislosti mezioborový př́stup. Praha: Úřad vlády České republiky - Národní monitorovací středisko pro drogy a drogové závislosti. $343 \mathrm{~s}$.

Kolibáš, E., Novotný, V. (2007) Alkohol, drogy, závislosti. Bratislava: Univerzita Komenského. 260 s.

Možný, I. (2002) Česká společnost - Nejdůležitější fakta o kvalitě našeho života. Praha: Portál. 208 s.

Mühlpachr, P. (2002) K problematice vzdelávaní seniorú. In: Ǩehulka, Řehulkova: Učitelé a zdraví 4. Brno: Nakladatelství P. Křepelka, s. 191-203.

Nešpor, K. (2003) Návykové chování a závislost: současné poznatky a perspekiívy léčby. Praha: Portál. $151 \mathrm{~s}$.

Orosová, O. (2003) Prevencia - pomoc - rovesníci alebo „Preventívne nie nepoškodí...“Inovatívne metódy pomoci v prevencii drogových závislostí v školskej praxi. Košice: Univerzita Pavla Jozefa Šafárika. $186 \mathrm{~s}$.

Profous, J. (2011) Prúvodce alkoholovou závislostí - predevším pro ženy pijících partnerú. Praha: Galén. 108 s.

Strieženec, Š. (1999) Úvod do sociálnej práce. Bratislava: Cover Design. 215 s.

Vad'urová, H., Mühlpachr, P. (2005) Kvalita života - teoretická a metodologická východiska. Brno: Masarykova univerzita. $143 \mathrm{~s}$.

Zábranský, T. (2003) Drogová epidemiologie. Olomouc: Univerzita Palackého v Olomouci. 96 s. 


\section{QUALITY OF LIFE OF THE ADDICTS IN TREATMENT}

Abstract: the aim of the research was to analyze difference in quality of life of the addicts at the end of their treatment comparing to the beginning. The research sample consisted of 80 respondents, 57 men and 23 women in addiction treatment in Centre for drug addiction treatment Banská Bystrica ( $M=41,86$; $S D=11,58)$. To identify the quality of life the questionnaire WHOQOL - BREF (Dragomirecká, 2006) was used. We found significant differences in all the dimensions of quality of life and also in total quality of life and health status of the addicts at the end of the addiction treatment comparing to the beginning. The research outcomes we discuss.

Key words: quality of life, addiction, addiction treatment 